\title{
Potential of Bacterial Strains Isolated from Coastal Water for Wastewater Treatment and as Aqua-Feed Additives
}

\author{
Kyochan Kim ${ }^{1}$, Joo-Young Jung ${ }^{2, *} \mathbb{C}$ and Jong-Hee Kwon ${ }^{2,3, *}$ \\ 1 Department of Civil and Environmental Engineering, Korea Advanced Institute of Science and \\ Technology (KAIST), Daejeon 34141, Korea; chan1028@kaist.ac.kr \\ 2 Division of Applied Life Sciences (BK21), Gyeongsang National University, Jinju 52828, Korea \\ 3 Department of Food Science \& Technology, and Institute of Agriculture \& Life Science, Gyeongsang National \\ University, Jinju 660-701, Korea \\ * Correspondence: jyjung@pukyong.ac.kr (J.-Y.J.); jhkwon@gnu.ac.kr (J.-H.K.); \\ Tel.: +82-55-772-1901 (J.-Y.J. \& J.-H.K.)
}

check for updates

Citation: Kim, K.; Jung, J.-Y.; Kwon, J.-H. Potential of Bacterial Strains Isolated from Coastal Water for Wastewater Treatment and as Aqua-Feed Additives. Microorganisms 2021, 9, 2441. https://doi.org/ $10.3390 /$ microorganisms 9122441

Academic Editor: Jarl Bøgwald

Received: 4 November 2021

Accepted: 25 November 2021

Published: 26 November 2021

Publisher's Note: MDPI stays neutral with regard to jurisdictional claims in published maps and institutional affiliations.

Copyright: (c) 2021 by the authors. Licensee MDPI, Basel, Switzerland. This article is an open access article distributed under the terms and conditions of the Creative Commons Attribution (CC BY) license (https:// creativecommons.org/licenses/by/ $4.0 /)$.

\begin{abstract}
Bacteria have various and sustained effects on humans in various fields: molecular biology, biomedical science, environmental/food industry, etc. This study was conducted to evaluate the wastewater treatment capacity and feed-additive fish-growth effect of four strains of bacteria: Pseudoalteromonas mariniglutinosa, Psychrobacter celer, Bacillus albus, and Bacillus safensis. In a wastewater degradation experiment, (i) nitrate- $\mathrm{N}$ and nitrite- $\mathrm{N}$ were removed within $1 \mathrm{~h}$ in all of the 4 bacterial strains; (ii) the removal rates of TAN and TN were higher in all of the strains relative to the B. subtilis. In a feed-additive experiment $\left(5 \% \mathrm{Kg}^{-1}\right)$, (i) the growth of fish was higher in all of the 4 bacterial strains with the $B$. subtilis relative to the commercial feed; (ii) there was no significant growth difference for $B$. albus and B. safensis relative to the B. subtilis, but growth was higher in $P$. mariniglutinosa and $P$. celer. The results indicated that the 4 bacterial strains can be effectively utilized for biological wastewater treatment processes and as aqua-feed.
\end{abstract}

Keywords: Pseudoalteromonas mariniglutinosa; Psychrobacter celer; Bacillus albus; Bacillus safensis; wastewater treatment; aqua-feed additives

\section{Introduction}

Bacteria, the first living organisms on Earth, have various and sustained effects on humans in various fields. In the fields of molecular biology and biomedical science, Escherichia coli sp. (gram-negative) plays a role in supplying the body with menaquinone (Vitamin K); with Mycobacterium phlei, Lactobacillus subtilis Natto, and Staphylococcus aureus, which animals cannot synthesize [1-3], it produces insulin to help diabetic patients [4-6]; and in the environmental field, it is used as an important water-quality indicator [7-9]. In the chemical industry, Bacillus sp. (gram-positive) is utilized as an intermediary for butanediol production (e.g., Bacillus velezensis, Bacillus toyonensis, Bacillus sapensis, Bacillus licheniformis) [10-12]; in the environmental industry, for biological wastewater treatment (e.g., Bacillus subtilis, Bacillus thuringiensis, Bacillus mycobacterium) [13-15], and in the food industry, for fermentation and a food additive (e.g., Bacillus licheniformis, Bacillus natto, Bacillus subtilis, Bacillus amyloliquefaciens) $[10,16,17]$.

In the wastewater treatment, a major problem to be solved is the removal of high organic loads, especially nitrogen and phosphorus, which contribute to eutrophication and, in this regard, biological treatment has received significant attention relative to physical and chemical methods, due to its environmental-friendliness, cost-effectiveness, and sustainability [18-20]. Sphingomonas sp. (gram-negative) has shown a total nitrogen (TN) removal efficiency of $94.22 \%$ in nitrification and $90.10 \%$ in denitrification processes after $48 \mathrm{~h}$ [21]; Pseudomonas sp. mendocina (gram-negative) removed up to $100 \mathrm{mg} \mathrm{L}^{-1}$ ammonia in $12 \mathrm{~h}$ with no nitrite-N $\left(\mathrm{NO}_{2}-\mathrm{N}\right)$ accumulation, and $100 \mathrm{mg} \mathrm{L}{ }^{-1}$ nitrite-N $\left(\mathrm{NO}_{3}-\mathrm{N}\right)$ 
and $72.61 \mathrm{mg} \mathrm{L}{ }^{-1}$ nitrate-N $\left(\mathrm{NO}_{3}-\mathrm{N}\right)$ under aerobic conditions [22]; Acinetobacter sp. (gram-negative) indicated excellent removal abilities for ammonium (98.5\%), nitrate-N $\left(\mathrm{NO}_{3}-\mathrm{N}, 91.1 \%\right), \mathrm{TN}(97.9 \%)$, and chemical oxygen demand (COD, 93.5\%) under acidic conditions [23]. Other strains, namely Alcaligenes faecalis, Rhodococcus sp., Thiosphaera pantotropha, and Alcaligenes faecalis, also have been reported to remove nitrogen sources through biological nitrogen fixation [24-27]. In the food industry, feed additives such as probiotics, prebiotics, acidifiers and plant- or animal-derived extracts are defined as non-nutritive ingredients or non-nutritive components of ingredients [28-30], and the common probiotics used in aquaculture are derived from Saccharomyces, Lactobacillus, Bacillus, Lactococcus, Shewanella, Carnobacterium, Clostridium, Enterococcus, Leuconostoc, Aeromonas, and several other strains [31-34]. Bacillus sp., Lactobacillus sp. for cobia (Rachycentron canadum), Clostridium sp. on white shrimp (Litopenaeus vannamei), and Shewanella sp. on abalone (Haliotis discus hannai) have been used as dietary probiotics to enhance growth performance, intestine antioxidant capacity, activities in serum enzymes, cellular and humoral immune response, alternative complement pathway (ACP) activity, phagocytosis percentage (PP), and respiratory burst activity $[31,35,36]$.

This study was conducted to discover useful heterotrophic microorganisms not yet reported in many studies and, more specifically, to evaluate (i) their effectiveness in biologicalwastewater-treatment and (ii) aqua-feed additive applications in terms of extents of fish growth, respectively. We evaluated (i) the removal of total ammonia nitrogen (TAN), nitrite- $\mathrm{N}\left(\mathrm{NO}_{2}-\mathrm{N}\right)$, nitrate- $\mathrm{N}\left(\mathrm{NO}_{3}-\mathrm{N}\right)$, total nitrogen (TN), and total phosphorus (TP) for the biological water treatment and (ii) the effect on fish growth using the microorganisms freeze-dried biomass obtained from mass cultivation as a feed additive. For those purposes, 4 dominant bacterial strains, namely Pseudoalteromonas mariniglutinosa (gram-negative), Psychrobacter celer (gram-negative), Bacillus albus (gram-positive), and Bacillus safensis (gram-positive) were identified.

\section{Materials and Methods}

In general, the analyses were performed in triplicate at the minimum. Bacillus subtilis was used as a control in the water-quality-degradation experiment, and as a semi-control in the feed-additive experiment.

\subsection{Site Description and Strains Collection}

Microorganism samples were collected from three coastal sites at Chungcheongnamdo province $\left(36^{\circ} 55^{\prime} 28.8^{\prime \prime} \mathrm{N}, 126^{\circ} 48^{\prime} 08.0^{\prime \prime} \mathrm{E}\right)$, Jeollabukdo province $\left(35^{\circ} 52^{\prime} 07.3^{\prime \prime} \mathrm{N} 126^{\circ} 30^{\prime} 29.8^{\prime \prime} \mathrm{E}\right)$, and Jeju-island $\left(33^{\circ} 18^{\prime} 10.5^{\prime \prime} \mathrm{N}, 126^{\circ} 48^{\prime} 15.5^{\prime \prime} \mathrm{E}\right)$ in the Republic of Korea, and five dominant (fast-growing) candidate strains cultured in LB (Luria-Bertani, LB Broth, Miller, BD Difco ${ }^{\mathrm{TM}}$, Sparks, MD, USA) solid medium finally were selected: Pseudoalteromonas mariniglutinosa (gram-negative), Psychrobacter celer (gram-negative), Bacillus albus, Bacillus safensis, and Bacillus subtilis (Figure 1). All of the bacterial strains were confirmed by nucleotide-sequence analysis of the $16 \mathrm{~S}$ ribosomal RNA (rRNA). Direct cycle sequencing of the purified PCR products was performed using the Big Dye Terminator v3.1 Cycle Sequencing Kit (Applied Biosystems, Foster City, CA, USA) with the primers, and a BLAST similarity search of the $16 S$ rRNA was conducted of the National Centre for Biotechnology Information (NCBI) database using BLASTN (https:/ / blast.ncbi.nlm.nih.gov/Blast.cgi, accessed on 12 March 2019) [37]. Analysis of the nucleotide sequences and phylogenetic tree construction was followed by construction of a Maximum Likelihood (ML) phylogenetic tree from the NCBI database library.

\subsection{Cultivation and Harvesting of Bacteria}

The five strains were cultivated in three sets of $10 \mathrm{~L}$, sealed-cylindrical plastic bottles per strain with medium (glucose $5 \mathrm{~g} \mathrm{~L}^{-1}$, Yeast extract $3 \mathrm{~g} \mathrm{~L}^{-1}, \mathrm{NaCl} 10 \mathrm{~g} \mathrm{~L}^{-1}$, Tryptone $\left.8 \mathrm{~g} \mathrm{~L}^{-1}\right)$. Constant aeration $\left(250 \mathrm{~mL} \mathrm{~min}^{-1}\right)$ was provided by air stones placed on the bottom to maintain the oxygen level, and the water temperature was maintained at $28{ }^{\circ} \mathrm{C}$. 
After $30 \mathrm{~h}$, the bacteria were harvested by a dynamic filtration module entailing rotation of a perforated disk (FMX B-class [bench-scale, BKT Co. Ltd., Daejeon, Korea]) [38]. Upon completion of the filtration, the concentrates of bacteria were freeze-dried for 7 days in a pre-weighed tube.

(a)

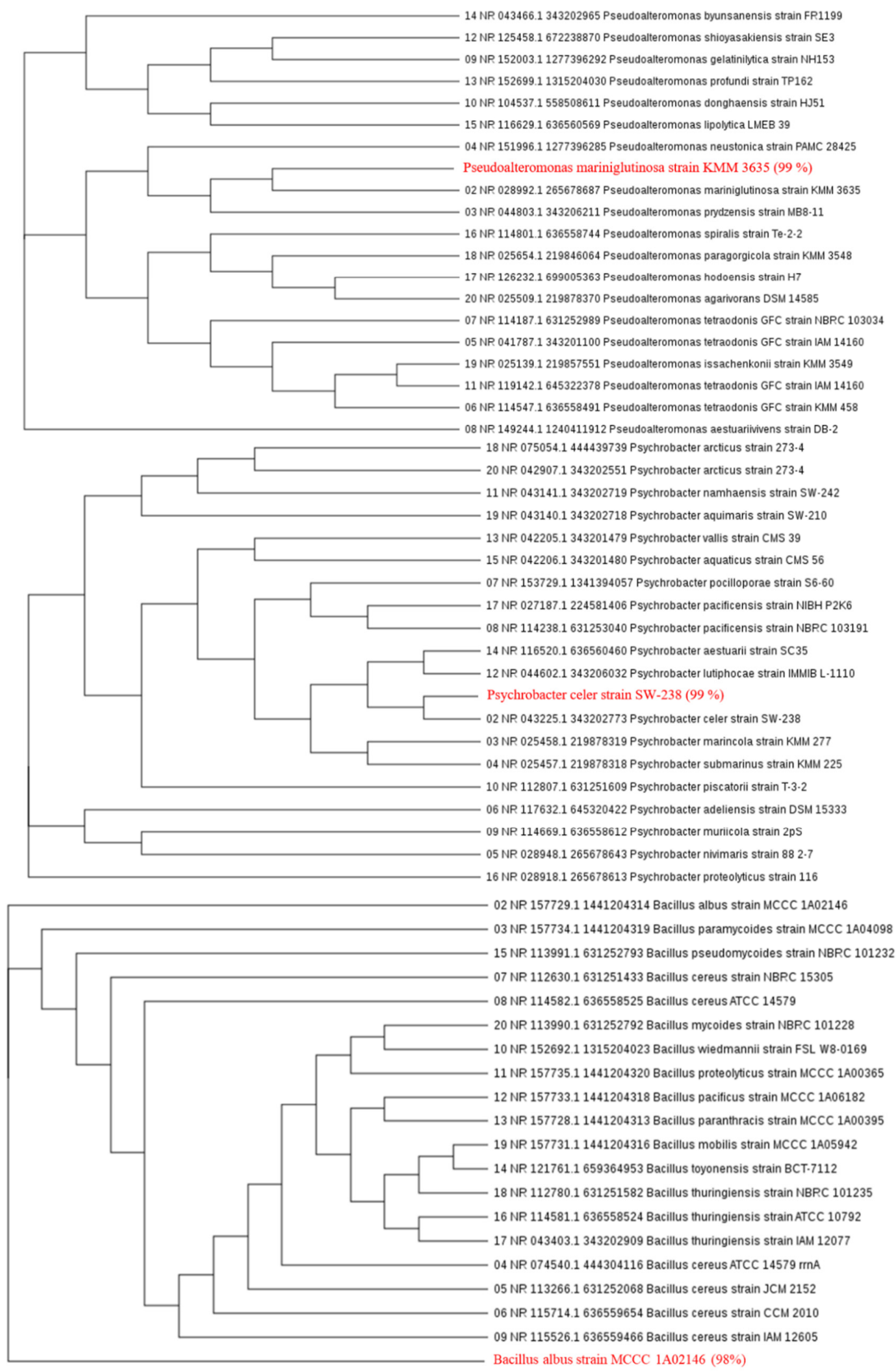

Figure 1. Cont. 
(d)

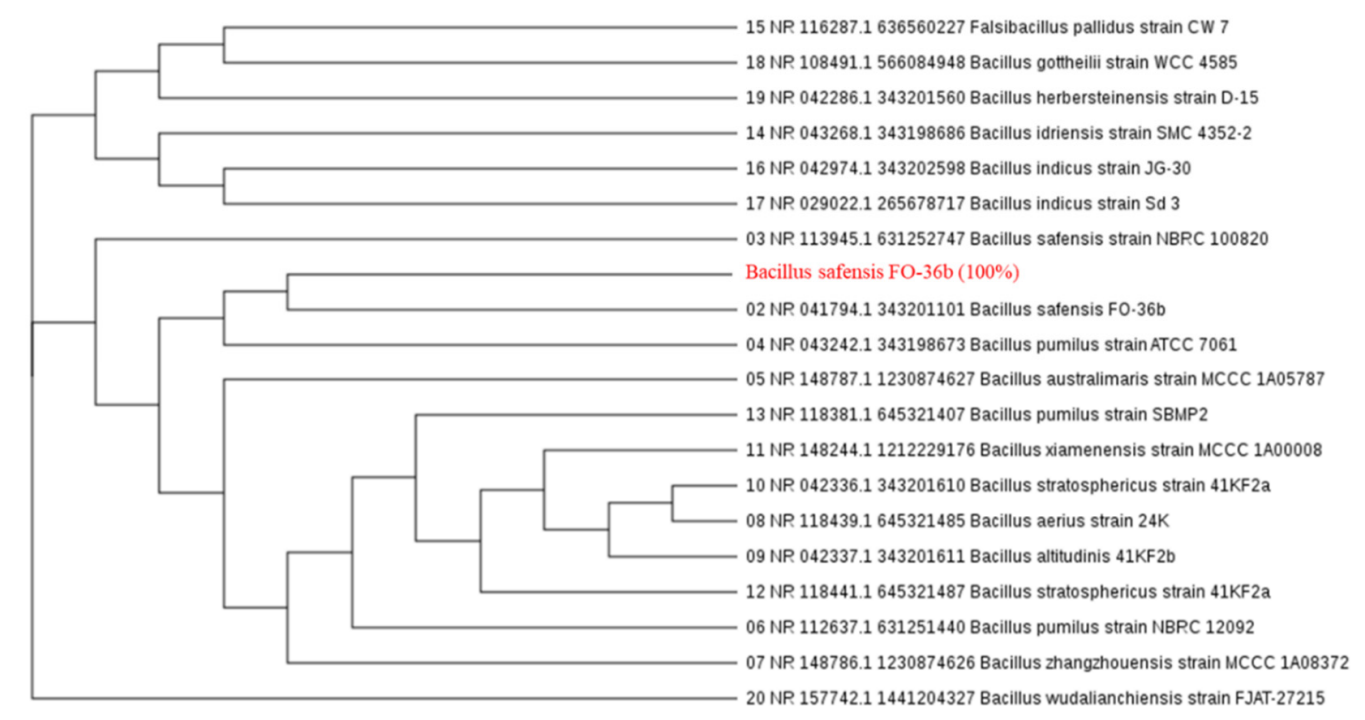

(e)

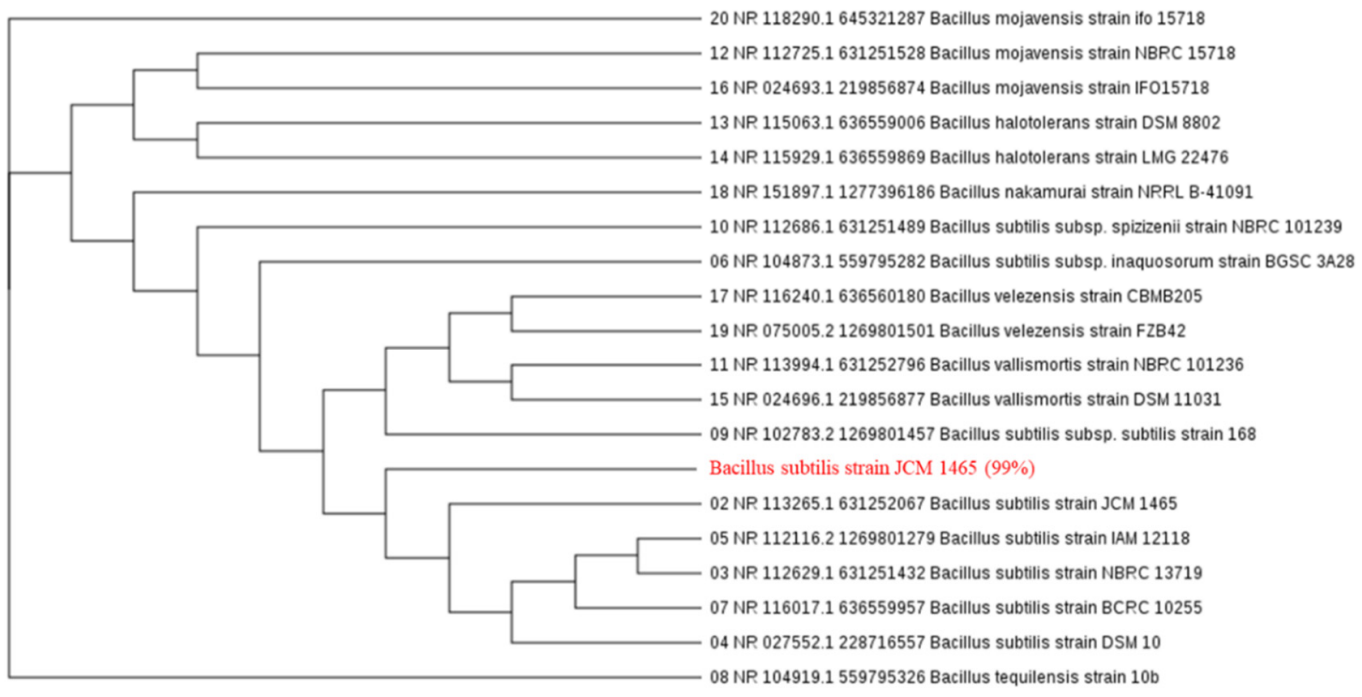

Figure 1. The phylogenetic tree derived from neighbor-joining analysis of partial 16S rRNA gene sequence: (a) Pseudoalteromonas mariniglutinosa, (b) Psychrobacter celer, (c) Bacillus albus, (d) Bacillus safensis, and (e) Bacillus subtilis.

\subsection{Evaluation of Biological Wastewater Treatment}

Domestic-sewage wastewater was collected from the National Municipal Wastewater Treatment Plant located in Gunsan city ( $\left.35^{\circ} 58^{\prime} 14.2^{\prime \prime} \mathrm{N} 126^{\circ} 34^{\prime} 22.4^{\prime \prime} \mathrm{E}\right)$, and solid particles therein were removed by GF/C glass-fiber filter paper $(0.45 \mu \mathrm{m}$, Whatman, Maidstone, UK). For the experiment, the average concentration of the five strains for the inoculum in the filtered wastewater ( 1 L cylindrical bioreactor) was $7.14 \times 10^{7}$ colony forming units (CFU), and it was maintained with a constant air flow $\left(200 \mathrm{~mL} \mathrm{~min}^{-1}\right)$ at $28{ }^{\circ} \mathrm{C}$. To induce bacterial growth, $1 \mathrm{~g} \mathrm{~L}^{-1}$ of glucose was added to the filtered wastewater. Samples were taken every hour to measure the total ammonia nitrogen (TAN), nitrite-N, nitrate-N, total nitrogen (TN), and total phosphorus (TP).

The supernatant was passed through a $0.2 \mu \mathrm{m}$ syringe filter, and the TAN, nitrite-N, nitrate-N concentrations were quantified by ion chromatography (883 Basic IC Plus, Metrohm, Herisau, Switzerland, LOD 0.02 0.27 $\mu \mathrm{g} \mathrm{L}^{-1}$ ), and TN and TP concentrations were measured by water-analysis kits (Nitrogen VARIO, total LR and Phosphate-total LR, Aqualytic ${ }^{\circledR}$, Dortmund, Germany, $>$ ppm). For analysis of the nitrate-N and nitrite-N, an anion column Metrosep A Supp $5(150 \mathrm{~mm} \times 4.0 \mathrm{~mm}$, Metrohm, Switzerland) was used, with eluent consisting of $3.2 \mathrm{mM} \mathrm{Na} 2 \mathrm{CO}_{3}$ and $1 \mathrm{mM} \mathrm{NaHCO}$ supplied to the column at a flow rate of $0.7 \mathrm{~mL} \mathrm{~min}^{-1}$. For quantification of the TAN concentration, a cation 
column MetrosepC4 (150 mm $\times 4.0 \mathrm{~mm}$, Metrohm, Switzerland) with eluent containing $1.7 \mathrm{mM} \mathrm{HNO}_{3}$ and $0.7 \mathrm{mM}$ PDCA (2,6-Pyridinedicarboxylic acid) supplied at a flow rate of $0.9 \mathrm{~mL} \mathrm{~min}^{-1}$ was used [39].

\subsection{Preparation of Experimental Diets (5\% Bacterial Feed Additives), and Fish and Rearing Conditions}

Five experimental diets of freeze-dried bacteria biomass $\left(5 \% \mathrm{Kg}^{-1}\right)$ added to commercial feed containing $47.44 \%$ crude protein and 5.65\% crude lipid were prepared. The diets were well mixed with a blender, pelletized by a pellet-extruder, dried over the course of $72 \mathrm{~h}$ at $25{ }^{\circ} \mathrm{C}$, to an approximately $9-10 \%$ moisture level, and finally stored at $-20{ }^{\circ} \mathrm{C}$ until use. The experiment was conducted for 8 weeks. Thirty (30) juvenile amur catfish (Silurus asotus) (initial body weight, $34.2 \mathrm{~g}$ ) obtained from a local fish farm were distributed into $200 \mathrm{~L}$ plastic tanks (water volume: $150 \mathrm{~L})$. Experimental diets $\left(5 \% \mathrm{Kg}^{-1}\right.$ of each bacteria) were supplied to the fish four times daily $(9: 00,13: 00,17: 00,21: 00)$ by satiation. The water was $40 \%$ replaced daily, constant aeration $\left(5 \mathrm{~L} \mathrm{~min}^{-1}\right)$ was provided by air stones placed on the bottom to maintain the oxygen level ( $\mathrm{DO},>5 \mathrm{mg} \mathrm{L}^{-1}$ ), and the water temperature $\left(25-26^{\circ} \mathrm{C}\right)$ and $\mathrm{pH}(7-8)$ were maintained under a 16-h light/8-h dark photoperiod cycle.

\subsection{Growth Performance and Proximate Composition Analysis}

At the end of the feeding trial, 10 fish were randomly selected from each tank and weighed to determine the weight gain (WG), feed efficiency (FE), specific growth rate (SGR), and survival rate. A proximate composition analysis of the samples (whole body) was performed using the standard AOAC methods [40]. Preparatorily, strains of bacteria and fish were freeze-dried for $48 \mathrm{~h}$. The moisture contents were determined by means of a dry oven at $105^{\circ} \mathrm{C}$, and the ash contents by combustion at $550{ }^{\circ} \mathrm{C}$. The crude protein was analyzed by the Kjedahl method, and the crude lipid was analyzed by soxhlet extraction using the soxhlet system 1046 (Tecator AB, Hoganas, Sweden) [41].

\subsection{Amino Acid Compositions}

Strains of bacteria and fish (whole body) were freeze-dried for amino acid (AA) analysis [42]. A total of $0.02 \mathrm{~g}$ of sample was hydrolyzed with $15 \mathrm{~mL}$ of $6 \mathrm{~N} \mathrm{HCl}$ at $110{ }^{\circ} \mathrm{C}$ for $24 \mathrm{~h}$. The hydrolyzed samples, in distilled water within a $50 \mathrm{~mL}$ flask, were evaporated and recovered in sodium citrate buffer $(0.2 \mathrm{~N}, \mathrm{pH} 2.2)$. After filtration $(0.2 \mu \mathrm{m})$, the samples were analyzed with ninhydrin at $570 \mathrm{~nm}$ and $440 \mathrm{~nm}$ using a $\mathrm{S} 433$ amino acid analyzer (Sykam, Gilching, Germany, >ppm). For methionine and cystine hydrolysis, performic acid was used in place of $6 \mathrm{~N} \mathrm{HCl}$.

\subsection{Fatty Acid Methyl Ester (FAME) Compositions}

Freeze-dried strains of bacteria and fish powder (whole body) were treated with chloroform/methanol $(2: 1, v / v)$, and lipids were determined using the modified Folch method [41]. Methanol and sulfuric acid were added, after which the solution was incubated at $100{ }^{\circ} \mathrm{C}$ for $20 \mathrm{~min}$ for fatty acid methyl ester (FAME) conversion. Heptadecanoic acid was used as an internal standard. The organic phase was separated by $0.3 \mathrm{M} \mathrm{NaOH}$, then recovered by centrifugation at $4000 \mathrm{rpm}$ for $10 \mathrm{~min}$. The FAMEs were measured by gas chromatography (HP 6890, Agilent, Santa Clara, CA, USA, LOD 3.9 28.7 $\mathrm{mg} \mathrm{L}^{-1}$ ) with a flame-ionized detector and HP-INNOWax capillary column $(30 \mathrm{~m} \times 0.32 \mathrm{~mm} \times 0.5 \mu \mathrm{m}$, Agilent, Santa Clara, CA, USA). The temperatures of the injection port and detector were 250 and $280^{\circ} \mathrm{C}$, respectively. The GC column temperature profile was as follows: (1) initial temperature $50{ }^{\circ} \mathrm{C}$ for $1 \mathrm{~min}$; (2) increased to $200{ }^{\circ} \mathrm{C}$ at $15^{\circ} \mathrm{C} \mathrm{min}-1$, held for $9 \mathrm{~min}$; and (3) increased to $250{ }^{\circ} \mathrm{C}$ at $2{ }^{\circ} \mathrm{C} \mathrm{min}{ }^{-1}$; held for $2 \mathrm{~min}$. The fatty acids were identified by comparing the retention times with those of standard fatty acids (37 Component FAME Mix, 
Supelco, Bellefonte, PA, USA) and quantified using the peak areas on the chromatogram with the internal standard [43]. The FAME content was calculated as

$$
\text { FAME content }\left(\%, \frac{w}{w}\right)=\frac{\text { weight of FAME obtained after transeseterification }}{\text { weight of fish whole body }} \times 100
$$

\subsection{Statistical Analysis}

All of the data were analyzed by one-way ANOVA (SPSS Inc., Chicago, IL, USA) to test the effects of the treatments. When a significant treatment effect was observed, a Tukey HSD test was applied for comparison of the means. The treatment effects were considered at the $5 \%$ level of significance $(p<0.05)$.

\section{Results and Discussion}

\subsection{Identification of Strains}

Hundreds of microbial strains were classified from the samples collected from the water of Chungcheongnamdo provine, Jeollabukdo province, and Jeju-island. The results of the analysis are shown in three clusters (Figure 1). After BLASTn analysis, similarity for each strain was 99\% (Pseudoalteromonas mariniglutinosa to KMM3635, Figure 1a), 99\% (Psychrobacter celer to SW-238, Figure 1b). 98\% (Bacillus albus to MCCC 1A02146, Figure 1c), 100\% (Bacillus safensis to FO-36b, Figure 1d), and 99\% (Bacillus subtilis to JCM 1465, Figure 1e).

\subsection{Effects of 4 Candidate Strains on Nutrient Removal}

Bacillus subtillis is one of the commonly used bacteria in biological wastewater treatment processes [44-46]. Total ammonia nitrogen (TAN, ionized ammonia as nitrogen plus ionized ammonia as nitrogen, Figure 2a) was removed faster in all of the experimental groups (four strains of bacteria) relative to the control (B. subtilis), and the removal rate within $1 \mathrm{~h}$ was $97.5 \%$ (control, B. subtilis) and $100 \%$ (all of the experimental groups, i.e., the four strains of bacteria). Nitrite-N $\left(\mathrm{NO}_{2}-\mathrm{N}\right.$, Figure $\left.2 \mathrm{~b}\right)$ and nitrate- $\mathrm{N}\left(\mathrm{NO}_{3}-\mathrm{N}\right.$, Figure $\left.2 \mathrm{c}\right)$ were almost completely removed within $1 \mathrm{~h}$ in both the control (B. subtilis) and the 4 experimental groups (strains of bacteria), and the removal rate of total nitrogen (TN, Figure $2 \mathrm{~d}$ ) was in the order of Pseudoalteromonas mariniglutinosa (96.1\%, gram-), B. safensis $(79.9 \%$, gram +$)$, B. albus $(79.9 \%$, gram +$)$, Psychrobacter celer $(78.0 \%$, gram -$)$, and B. subtilis $(72.6 \%$, gram+). Considering that TN (precisely: total dissolved nitrogen, TDN) is the total amount of nitrogen compounds composed of dissolved organic nitrogen (DON) (e.g., free amino acids, urea, nucleic acids, trihalomethanes [THMs], dihaloacetic acids [DHAAs] [47,48]), dissolved inorganic nitrogen [DIN], TAN $\left(\mathrm{NH}_{4}{ }^{+}+\mathrm{NH}_{3}\right)$, nitrite- $\mathrm{N}\left(\mathrm{NO}_{2}-\mathrm{N}\right)$, nitrate- $\mathrm{N}$ $\left(\mathrm{NO}_{3}-\mathrm{N}\right)$, or nitrous oxide [ $\left.\mathrm{N}_{2} \mathrm{O}\right]$ (depending on the oxidation state in water), and assuming, based on this, that DON is simply determined by subtracting DIN concentrations from TN [49], the order of the four strains of bacteria (four strains + control strain) for the amount and rate of dissolved organic nitrogen (DON) in wastewater degraded by them, was: Pseudoalteromonas mariniglutinosa (27.45 $\left.\mathrm{mg} \mathrm{L}^{-1}, 92.3 \%\right)$, B. safensis $\left(17.95 \mathrm{mg} \mathrm{L}^{-1}, 60.3 \%\right)$, B. albus (17.95 $\left.\mathrm{mg} \mathrm{L}^{-1}, 60.3 \%\right)$, Psychrobacter celer $\left(16.85 \mathrm{mg} \mathrm{L}^{-1}, 56.6 \%\right)$, and B. subtilis (13.65 $\left.\mathrm{mg} \mathrm{L}^{-1}, 45.9 \%\right)$, respectively. The amount and rate of total phosphorus (TP, Figure 2e) removal were high in the order of B. safensis $\left(5.79 \mathrm{mg} \mathrm{L}^{-1}, 82.7 \%\right)$, B. albus $\left(5.70 \mathrm{mg} \mathrm{L}^{-1}\right.$, $81.4 \%)$, B. subtilis (5.64 $\left.\mathrm{mg} \mathrm{L}^{-1}, 80.6 \%\right)$, Psychrobacter celer $\left(5.62 \mathrm{mg} \mathrm{L}^{-1}, 80.3 \%\right)$, and Pseudoalteromonas mariniglutinosa $\left(5.53 \mathrm{mg} \mathrm{L}^{-1}, 79.0 \%\right)$, and there was no significant difference between the control (B. subtilis) and the 4 experimental groups (strains of bacteria). 
(a)

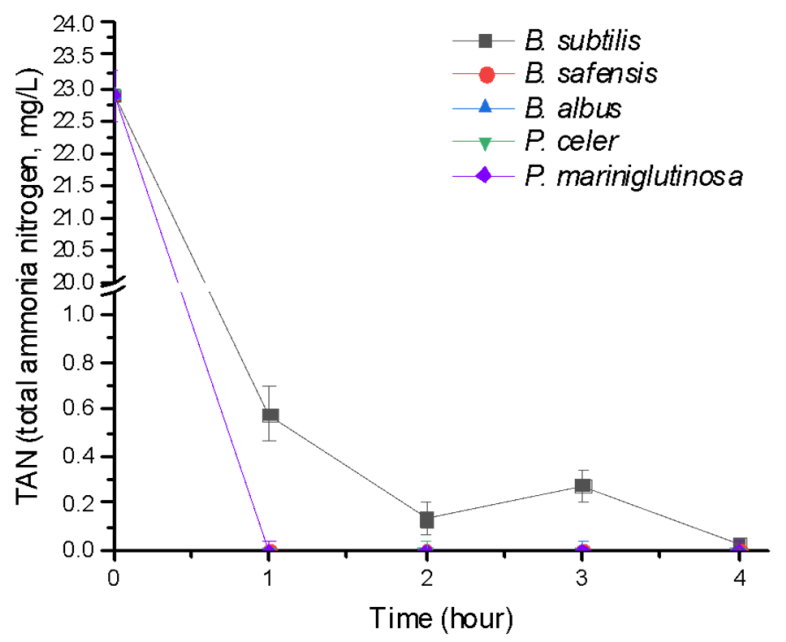

(c)

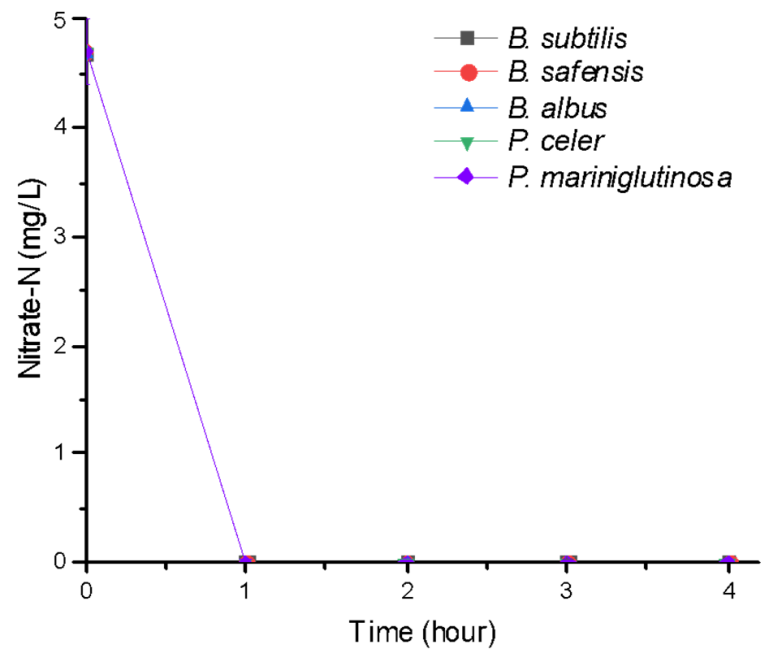

(b)

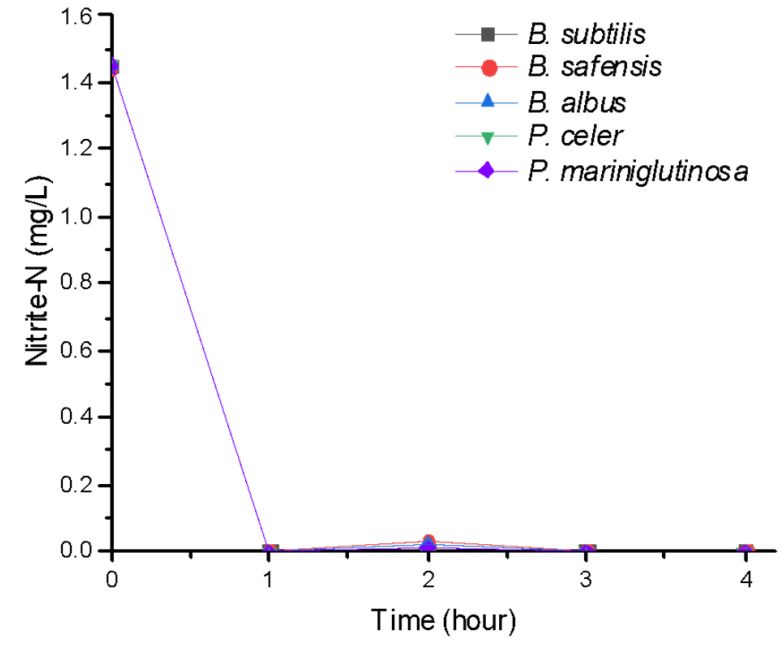

(d)

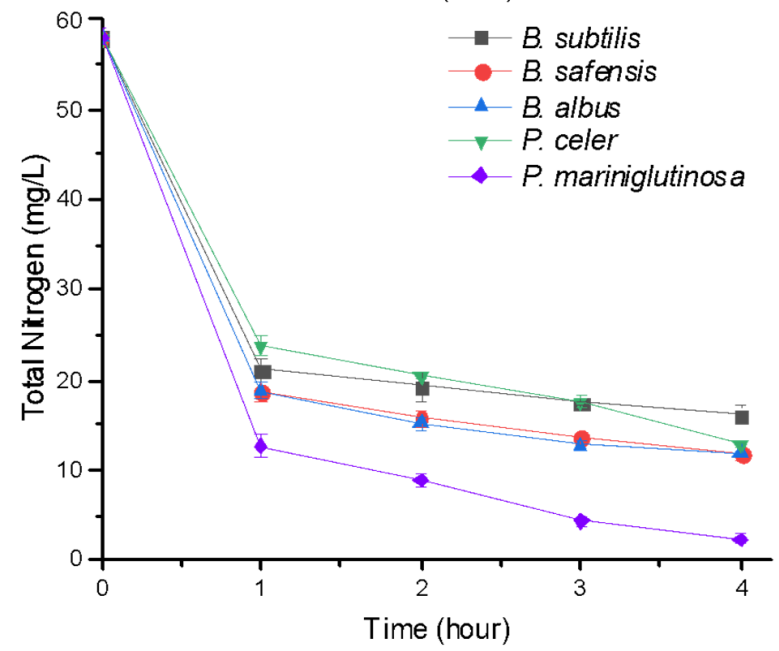

- B. subtilis

- B. safensis

$\triangle$ B. albus

$\checkmark$ - P. celer

- P. mariniglutinosa

(e)

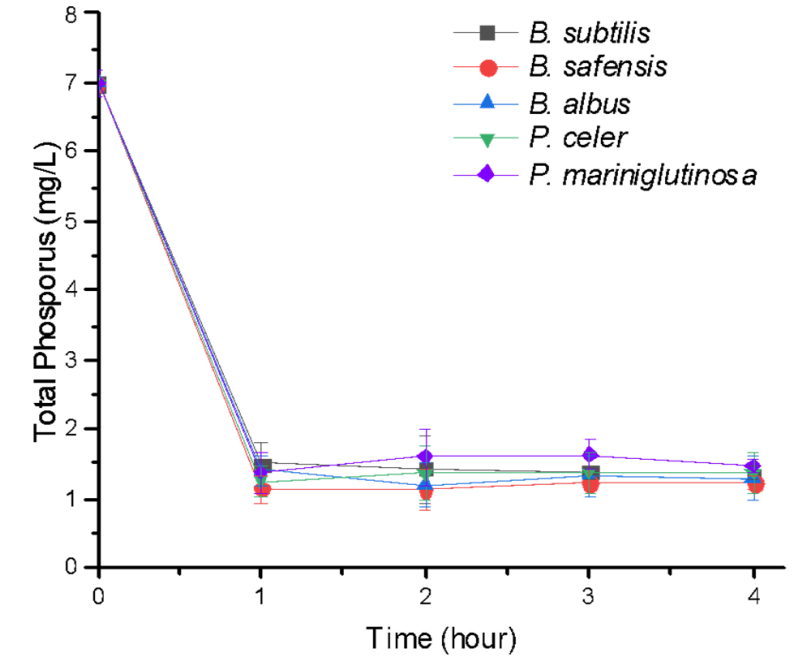

Figure 2. Nutrient-removal efficacy: (a) TAN (total ammonia nitrogen), (b) Nitrite- $\mathrm{N}\left(\mathrm{NO}_{2}-\mathrm{N}\right)$, (c) $\mathrm{Nitrate}^{-\mathrm{N}}\left(\mathrm{NO}{ }^{-}{ }^{-} \mathrm{N}\right)$, (d) Total nitrogen (TN), and (e) Total phosphorus (TP). Groups: Bacillus subtilis, Bacillus safensis, Bacillus albus, Psychrobacter celer, and Pseudoalteromonas mariniglutinosa.

Recently, simultaneous heterotrophic nitrification and aerobic denitrification (SND) bacteria including Bacillus sp. have emerged as a promising approach to nitrogen removal by microorganisms in wastewater treatment [22,50-52]. This type of bacteria consequently shows the capability for removal of ammonium-nitrogen, nitrite-nitrogen and nitratenitrogen through heterotrophic nitrification $\left(\mathrm{NH}_{4}{ }^{+} \rightarrow \mathrm{NH}_{2} \mathrm{OH} \rightarrow \mathrm{NO}_{2}{ }^{-} \rightarrow \mathrm{NO}_{3}{ }^{-}\right)$and 
aerobic denitrification $\left(\mathrm{NO}_{3}{ }^{-} \rightarrow \mathrm{NO}_{2}{ }^{-} \rightarrow \mathrm{N}_{2} \mathrm{O} \rightarrow \mathrm{N}_{2}\right.$ ) under aerobic conditions [53,54]. Therefore, the four strains of bacteria belong to SND bacteria, according to the present results. In addition, there are microorganisms such as ammonia-oxidizing bacteria (AOB), nitrite-oxidizing bacteria (NOB), and denitrification bacteria that prefer specific nitrogen sources for their growth, but there are also cases where they selectively absorb nitrogen depending on the environment. For example, Pseudomonas sp. (gram-) prefer nitrate-N $\left(\mathrm{NO}_{3}-\mathrm{N}\right)$, Bacillus sp. (gram+) and Gordonia sp. (gram+) prefer ammonia, and Chlorella sp. and Scenedesmus sp. (eukaryotes, autotrophs) prefer nitrite- $\mathrm{N}\left(\mathrm{NO}_{2}-\mathrm{N}\right)$ [55-57]. In the light of the amounts of the different nitrogen sources and the removal rates in the results of the current study (Figure 2), it was considered that all of the strains prefer TAN to the other nitrogen sources. For more accurate and comprehensive information on this, additional and more specific studies are required.

\subsection{Evaluation of Four Strains of Bacteria as Feed Additives for Fish-Growth Performance}

The growth performance and feed efficiency data on catfish fed with commercial feed and freeze-dried bacteria biomass-supplemented diets $\left(5 \% \mathrm{Kg}^{-1}\right)$ are provided in Table 1. Similarly to the results of many previous studies [58-60], the growth of the fish fed the semi-control (B. subtilis-supplemented diet) was greater than that of the fish fed the control (commercial feed), suggesting that useful microorganisms, from a nutritional point of view, can have a positive effect on fish growth by playing a role as feed additives or probiotics. The overall values of weight gain (WG), feed efficiency ratio (FE), and specific growth rate (SGR) were significantly different between the B. subtilis-supplemented and 4 bacteria-strain-supplemented diets. This supports the contention that the amount and the type or properties of proteins affecting the digestibility of diets can have an effect on the growth of fish $[28,61]$. In this respect, note the following values (relative to the commercial-feed control): B. subtilis (29.10 $\left.\mathrm{g} \mathrm{Kg}^{-1}\right)$, B. albus $\left(21.02 \mathrm{~g} \mathrm{Kg}^{-1}\right)$, B. safensis (28.40 $\left.\mathrm{g} \mathrm{Kg}^{-1}\right)$, Pseudoalteromonas mariniglutinosa (35.30 $\mathrm{g} \mathrm{Kg}^{-1}$ ), and Psychrobacter celer (34.12 $\mathrm{g} \mathrm{Kg}^{-1}$ ) (Table 2a).

The total protein and lipid contents in the whole catfish body ranged from 14.08 to 16.35 and from 5.23 to $6.82 \%$, respectively (Table $2 b$ ). The protein/lipid content ranges for each group were $15.45 / 5.23 \%$ (B. subtilis), 15.41/6.26\% (B. albus), 14.10/5.37\% (B. safensis), 14.08/5.57\% (Pseudoalteromonas mariniglutinosa), and 16.35/6.82\% (Psychrobacter celer), values which were within the ranges of other, relevant studies [62-66].

Table 1. Growth performance of Amur catfish fed with commercial feed and 5\% freeze-dried bacteria biomass-supplemented feed at end of 8-week experiment ${ }^{1}$.

\begin{tabular}{|c|c|c|c|c|c|c|}
\hline & C. F ${ }^{6}$ (Con) & $\begin{array}{c}\text { B.subtilis } \\
\text { (Semi-control) }\end{array}$ & B. albus & B. safensis & $\begin{array}{l}\text { P. marinigluti- } \\
\text { nosa }\end{array}$ & P. celer \\
\hline $\begin{array}{c}\text { Initial mean } \\
\text { weight }\left(\mathrm{g} \mathrm{fish}^{-1}\right)\end{array}$ & $34.2 \pm 0.1$ & $34.1 \pm 0.1$ & $34.0 \pm 0.1$ & $34.1 \pm 0.1$ & $34.2 \pm 0.1$ & $34.1 \pm 0.1$ \\
\hline $\begin{array}{c}\text { Final mean } \\
\text { weight }\left(\mathrm{g} \text { fish }^{-1}\right)\end{array}$ & $75.3 \pm 1.5^{c}$ & $79.8 \pm 1.1^{b}$ & $81.7 \pm 1.7^{b}$ & $81.1 \pm 1.6^{b}$ & $92.8 \pm 2.5^{\mathrm{a}}$ & $91.3 \pm 2.5^{a}$ \\
\hline WG $(\%)^{2}$ & $120.2 \pm 4.5^{\mathrm{d}}$ & $134.0 \pm 3.3^{c}$ & $140.3 \pm 5.0^{b}$ & $137.8 \pm 4.6^{\mathrm{bc}}$ & 171. $\pm 7.2^{\mathrm{a}}$ & $167.7 \pm 7.3^{\mathrm{a}}$ \\
\hline $\mathrm{FE}(\%)^{3}$ & $123.3 \pm 2.1^{c}$ & $137.1 \pm 5.4^{b}$ & $143.1 \pm 3.8^{b}$ & $141.0 \pm 6.6^{b}$ & $175.8 \pm 5.3^{\mathrm{a}}$ & $171.6 \pm 7.1^{\mathrm{a}}$ \\
\hline SGR (\%/day) 4 & $1.41 \pm 0.04^{\mathrm{d}}$ & $1.52 \pm 0.03^{c}$ & $1.57 \pm 0.04^{b}$ & $1.55 \pm 0.03^{b c}$ & $1.78 \pm 0.05^{\mathrm{a}}$ & $1.76 \pm 0.05^{\mathrm{a}}$ \\
\hline Survival $(\%)^{5}$ & 100 & 100 & 100 & 100 & 100 & 100 \\
\hline
\end{tabular}

${ }^{1}$ Values are means from triplicate groups of fish where the values in each row with different superscripts are significantly different $(p<0.05) .{ }^{2}$ Weight gain $(W G, \%)=($ final weight - initial weight $) \times 100 /$ initial weight. ${ }^{3}$ Feed efficiency ratios $($ FE, $\%)=($ wet weight gain/dry feed intake) $\times 100 .{ }^{4}$ Specific growth rates $\left(\right.$ SGR, \%/day) $=\left(\log _{\mathrm{e}}\right.$ final weight $-\log _{\mathrm{e}}$ initial weight $) \times 100 /$ days. ${ }^{5}$ Survival rate $(\%)$ $=\left(\right.$ initial number of fish-dead fish) $\times 100 /$ initial number of fish. ${ }^{6}$ Commercial feed containing $47.44 \%$ protein and $5.65 \%$ lipid, Korea. 
Table 2. Whole-body proximate compositions of bacterial strains and Amur catfish fed with commercial feed and $5 \%$ freeze-dried bacteria biomass-supplemented feed at end of 8-week experiment ${ }^{1}$.

\begin{tabular}{|c|c|c|c|c|c|c|c|c|c|c|c|}
\hline & \multicolumn{5}{|c|}{ Microorganisms (a) $^{2}$} & \multicolumn{6}{|c|}{ Amur Catfish (b) ${ }^{3}$} \\
\hline & $\begin{array}{c}\text { B. } \\
\text { subtilis }\end{array}$ & $\begin{array}{c}\text { B. } \\
\text { albus }\end{array}$ & $\begin{array}{c}B . \\
\text { safensis }\end{array}$ & $\begin{array}{l}P . \\
\text { marinigluti- } \\
\text { nosa }\end{array}$ & P. celer & $\begin{array}{l}\text { C.F } \\
\text { (Con) }\end{array}$ & $\begin{array}{c}B . \\
\text { subtilis } \\
\text { (Semi- } \\
\text { control) }\end{array}$ & $\begin{array}{c}\text { B. } \\
\text { albus }\end{array}$ & $\begin{array}{c}\text { B. } \\
\text { safensis }\end{array}$ & $\begin{array}{c}P . \\
\text { marinigluti- } \\
\text { nosa }\end{array}$ & P. celer \\
\hline Moisture & $1.26^{\mathrm{a}}$ & $1.39^{\mathrm{a}}$ & $1.28^{\mathrm{a}}$ & $0.16^{\mathrm{b}}$ & $0.11^{\mathrm{b}}$ & $76.03^{b}$ & $75.94^{b}$ & $75.76^{\mathrm{b}}$ & $77.84^{a}$ & $78.52^{a}$ & $75.01^{b}$ \\
\hline Protein & $58.36^{c}$ & $42.05^{\mathrm{e}}$ & $56.81^{\mathrm{d}}$ & $70.61^{\mathrm{a}}$ & $68.34^{\mathrm{b}}$ & $15.57^{\mathrm{b}}$ & $15.45^{b}$ & $15.41^{\mathrm{b}}$ & $14.10^{c}$ & $14.08^{c}$ & $16.35^{a}$ \\
\hline Lipid & $0.56^{\mathrm{a}}$ & $0.44^{\mathrm{b}}$ & $0.48^{\mathrm{ab}}$ & $0.43^{\mathrm{b}}$ & $0.33^{c}$ & $6.25^{\mathrm{b}}$ & $5.23^{c}$ & $6.26^{\mathrm{b}}$ & $5.37^{c}$ & $5.57^{c}$ & $6.82^{\mathrm{a}}$ \\
\hline
\end{tabular}

${ }^{1}$ Values are means from triplicate groups of shrimps where the values in each row with different superscripts are significantly different $(p<0.05) .{ }^{2}$ Dry matter basis. ${ }^{3}$ Wet weight basis. ${ }^{4}$ Commercial feed containing $47.44 \%$ protein and $5.65 \%$ lipid, Korea.

The amino acid compositions of the microorganisms and fish fed with the commercial and microbial-supplemented diets are provided below (Table 3). As for the amino acid compositions of the microorganisms (Table $3 a$ ), all of the strains were found to contain the highest amounts of leucine (B. subtilis), lysine (B. albus and Pseudoalteromonas mariniglutinosa), arginine (B. safensis), and histidine (Psychrobacter celer) with the least amounts of methionine in essential amino acids (EAA); and, all of the strains were found to contain the highest amounts of glutamic acid with the least amounts of cysteine in non-essential amino acids (NEAA). For the fish fed with the commercial and microbial-supplemented diets (Table 3b), the highest and least amounts were methionine and histidine in the EAA, and glutamic acid and cysteine in the NEAA, in all of the groups.

Table 3. Amino acid compositions of bacterial strains and Amur catfish fed with commercial feed and $5 \%$ freeze-dried bacteria biomass-supplemented feed at end of 8-week experiment $(\%)^{1,2}$.

\begin{tabular}{|c|c|c|c|c|c|c|c|c|c|c|c|}
\hline & \multicolumn{5}{|c|}{ Microorganisms (a) } & \multicolumn{6}{|c|}{ Amur Catfish (b) } \\
\hline & $\begin{array}{c}\text { B. } \\
\text { subtilis }\end{array}$ & $\begin{array}{c}\text { B. } \\
\text { albus }\end{array}$ & $\begin{array}{c}B . \\
\text { safensis }\end{array}$ & $\begin{array}{c}P . \\
\text { marinigluti- } \\
\text { nosa }\end{array}$ & P. celer & C.F ${ }^{3}$ & $\begin{array}{c}\text { B. } \\
\text { subtilis }\end{array}$ & $\begin{array}{c}\text { B. } \\
\text { albus }\end{array}$ & $\begin{array}{c}\text { B. } \\
\text { safensis }\end{array}$ & $\begin{array}{c}P . \\
\text { marinigluti- } \\
\text { nosa }\end{array}$ & P. celer \\
\hline \multicolumn{12}{|c|}{ Essential amino acids (EAA) } \\
\hline Arginine & $2.50 \mathrm{~cd}$ & $2.29 \mathrm{~d}$ & $3.43^{\mathrm{a}}$ & $2.80^{b}$ & $2.52^{c}$ & $0.98^{b c}$ & $0.97 \mathrm{bcd}$ & $1.07^{\mathrm{a}}$ & $0.89^{\mathrm{d}}$ & $0.91^{\mathrm{cd}}$ & $1.02^{\mathrm{ab}}$ \\
\hline Threonine & $2.05^{b}$ & $1.53^{\mathrm{c}}$ & $2.02^{b}$ & $2.25^{\mathrm{a}}$ & $2.02^{b}$ & $0.69^{\mathrm{a}}$ & $0.65^{a b}$ & $0.66^{\mathrm{ab}}$ & $0.61 \mathrm{bc}$ & $0.56^{\mathrm{c}}$ & $0.68^{a}$ \\
\hline Valine & $2.96^{c}$ & $2.13^{\mathrm{e}}$ & $2.56^{\mathrm{d}}$ & $3.87^{\mathrm{a}}$ & $3.54^{\mathrm{b}}$ & $0.73^{\mathrm{a}}$ & $0.71^{\mathrm{a}}$ & $0.71^{\mathrm{a}}$ & $0.64^{\mathrm{b}}$ & $0.57^{\mathrm{c}}$ & $0.73^{\mathrm{a}}$ \\
\hline Isoleucine & $2.30^{c}$ & $1.84^{\mathrm{d}}$ & $2.21^{\mathrm{c}}$ & $2.92^{\mathrm{a}}$ & $2.64^{b}$ & $0.66^{\mathrm{a}}$ & $0.66^{\mathrm{a}}$ & $0.66^{\mathrm{a}}$ & $0.58^{b}$ & $0.53^{b}$ & $0.66^{\mathrm{a}}$ \\
\hline Leucine & $3.44^{b c}$ & $2.55^{\mathrm{d}}$ & $3.19^{c}$ & $3.76^{\mathrm{a}}$ & $3.47^{b}$ & $1.15^{\mathrm{a}}$ & $1.11^{\mathrm{a}}$ & $1.14^{\mathrm{a}}$ & $1.01^{\mathrm{b}}$ & $0.93^{b}$ & $1.19^{\mathrm{a}}$ \\
\hline Methionine & $0.65^{c}$ & $0.80^{\mathrm{b}}$ & $1.19^{\mathrm{a}}$ & $0.67^{c}$ & $0.46^{\mathrm{d}}$ & $2.57^{\mathrm{a}}$ & $1.86^{\mathrm{b}}$ & $1.36^{c}$ & $1.39^{c}$ & $1.84^{\mathrm{b}}$ & $1.42^{\mathrm{c}}$ \\
\hline Lysine & $3.35^{\mathrm{b}}$ & $2.63^{c}$ & $3.13^{b}$ & $3.91^{\mathrm{a}}$ & $3.81^{\mathrm{a}}$ & $1.26^{\mathrm{a}}$ & $1.25^{\mathrm{a}}$ & $1.25^{\mathrm{a}}$ & $1.10^{b}$ & $1.01^{\mathrm{b}}$ & $1.27^{\mathrm{a}}$ \\
\hline Phenylalanine & $2.15^{\mathrm{b}}$ & $1.47^{\mathrm{d}}$ & $1.90^{\mathrm{c}}$ & $2.33^{a}$ & $2.12^{b}$ & $0.65^{\mathrm{a}}$ & $0.63^{\mathrm{a}}$ & $0.64^{\mathrm{a}}$ & $0.56^{\mathrm{b}}$ & $0.53^{b}$ & $0.66^{\mathrm{a}}$ \\
\hline Histidine & $1.91^{\mathrm{d}}$ & $2.73^{c}$ & $2.64^{c}$ & $3.30^{b}$ & $4.44^{\mathrm{a}}$ & $0.50^{b}$ & $0.51^{\mathrm{ab}}$ & $0.49^{b}$ & $0.44^{c}$ & $0.41^{\mathrm{c}}$ & $0.54^{\mathrm{a}}$ \\
\hline Total & $21.31^{b}$ & $17.97^{\mathrm{c}}$ & $22.27^{b}$ & $25.81^{a}$ & $25.02^{\mathrm{a}}$ & $9.19^{\mathrm{a}}$ & $8.35^{b}$ & $7.98^{b}$ & $7.22^{c}$ & $7.29^{c}$ & $8.17^{b}$ \\
\hline \multicolumn{12}{|c|}{ Non-essential amino acids (NEAA) } \\
\hline Serine & $1.87^{\mathrm{a}}$ & $1.17^{\mathrm{d}}$ & $1.65^{\mathrm{b}}$ & $1.65^{\mathrm{b}}$ & $1.47^{\mathrm{c}}$ & $0.71^{\mathrm{ab}}$ & $0.66^{\mathrm{bcd}}$ & $0.68^{a b c}$ & $0.63^{\mathrm{cd}}$ & $0.61^{\mathrm{d}}$ & $0.73^{\mathrm{a}}$ \\
\hline $\begin{array}{c}\text { Glutamic } \\
\text { acid }\end{array}$ & $7.24^{\mathrm{c}}$ & $6.16^{\mathrm{d}}$ & $7.53^{c}$ & $9.63^{\mathrm{a}}$ & $8.48^{\mathrm{b}}$ & $2.16^{\mathrm{ab}}$ & $2.12^{b c}$ & $2.16^{\mathrm{ab}}$ & $1.96^{\mathrm{cd}}$ & $1.86^{\mathrm{d}}$ & $2.31^{\mathrm{a}}$ \\
\hline Proline & $2.15^{b}$ & $1.47^{\mathrm{c}}$ & $1.52^{\mathrm{c}}$ & $2.42^{\mathrm{a}}$ & $2.50^{\mathrm{a}}$ & $0.87^{\mathrm{b}}$ & $0.78^{c}$ & $0.86^{\mathrm{b}}$ & $0.83 \mathrm{bc}$ & $0.97^{\mathrm{a}}$ & $0.98^{\mathrm{a}}$ \\
\hline Glycine & $2.40^{\mathrm{b}}$ & $1.58^{\mathrm{d}}$ & $2.15^{\mathrm{c}}$ & $2.62^{\mathrm{a}}$ & $2.41^{b}$ & $1.17^{b}$ & $1.16^{\mathrm{b}}$ & $1.06^{\mathrm{c}}$ & $1.16^{\mathrm{b}}$ & $1.34^{\mathrm{a}}$ & $1.20^{\mathrm{b}}$ \\
\hline Alanine & $4.17^{\mathrm{b}}$ & $2.96^{c}$ & $3.29^{c}$ & $5.50^{\mathrm{a}}$ & $5.17^{\mathrm{a}}$ & $1.04^{\mathrm{a}}$ & $1.00^{\mathrm{ab}}$ & $0.94^{\mathrm{b}}$ & $0.94^{\mathrm{b}}$ & $0.97^{a b}$ & $1.03^{\mathrm{a}}$ \\
\hline Tyrosine & $1.24^{\mathrm{b}}$ & $1.18^{\mathrm{b}}$ & $1.44^{\mathrm{a}}$ & $1.38^{\mathrm{a}}$ & $1.19^{b}$ & $0.52^{\mathrm{ab}}$ & $0.48^{b c}$ & $0.52^{a b}$ & $0.45^{\mathrm{cd}}$ & $0.41^{\mathrm{d}}$ & $0.53^{\mathrm{a}}$ \\
\hline Aspartic acid & $4.68^{\mathrm{a}}$ & $3.57^{c}$ & $5.00^{\mathrm{a}}$ & $4.15^{b}$ & $4.02^{\mathrm{b}}$ & $1.50^{\mathrm{a}}$ & $1.48^{\mathrm{a}}$ & $1.48^{\mathrm{a}}$ & $1.33^{\mathrm{b}}$ & $1.25^{\mathrm{b}}$ & $1.55^{\mathrm{a}}$ \\
\hline Cysteine & $0.71^{\mathrm{b}}$ & $0.57^{c}$ & $0.80^{\mathrm{a}}$ & $0.40^{\mathrm{e}}$ & $0.49^{\mathrm{d}}$ & 0.13 & 0.10 & 0.10 & 0.09 & 0.09 & 0.09 \\
\hline Total & $24.46^{b c}$ & $18.66^{d}$ & $23.38^{c}$ & $27.75^{\mathrm{a}}$ & $25.73^{b}$ & $8.10^{a b}$ & $7.78^{a b c}$ & $7.80^{a b c}$ & $7.39^{c}$ & $7.50^{b c}$ & $8.42^{\mathrm{a}}$ \\
\hline
\end{tabular}

${ }^{1}$ Values are means from triplicate groups of shrimps where the values in each row with different superscripts are significantly different $(p<0.05) .{ }^{2}$ Dry matter basis. ${ }^{3}$ Commercial feed containing $47.44 \%$ protein and $5.65 \%$ lipid, Republic of Korea.

The fatty acid compositions of the microorganisms and fish fed with the commercial and microbial-supplemented diets are provided below (Table 4). All of the strains were found to contain the highest amounts of palmitic acid (C16:0) in both all of the strains (Table 4a) and in the fish (Table $4 \mathrm{~b}$ ). In the microorganisms (Table 4a), the sat- 
urated fatty acid (SFA) content was found to be high in the order of P. celer $(83.37 \%)$, B. safensis (81.79\%), B. albus (71.37\%), B. subtilis (61.64\%), and P. mariniglutinosa $(61.42 \%)$; the monounsaturated fatty acid (MUFA) content, in the order of B. subtilis $(21.39 \%)$, B. albus (18.13\%), P. ma'riniglutinosa $(17.21 \%)$, B. safensis $(14.29 \%)$, and P. celer $(11.65 \%)$, and in the polyunsaturated fatty acid (PUFA) content, in the order of P. mariniglutinosa $(21.37 \%)$, B. subtilis (16.97\%), B. albus (10.50\%), P. celer (4.98\%), and B. safensis (3.92\%). Interestingly, arachinodic acid (C20:0, ARA, one of the components of breast milk and a precursor to inflammation-inducer prostaglandin and leukotriene) was found in P. mariniglutinosa; meanwhile, eicosapentaenoic acid (C20:5n3, EPA) and docosahexaenoic acid (C22:6n3, DHA), conditionally essential fatty acids with ARA for humans and animals, were found in P. mariniglutinosa and P. celer, respectively. In the fish (Table $4 \mathrm{~b}$ ), there was no significant difference between SFA and MUFA among the control (commercial feed), semi-control (B. subtilis), or any of the experimental groups (four strains), except for PUFA. Myristic acid (C14:0), $\alpha$-Linolenic acid (C18:3n3), $\gamma$-Linolenic acid (C18:3n6), arachidic acid (C20:0), eicosatrienoic acid (C20:3n3), eicosapentaenoic acid (C20:5n3), erucic acid (C22:1n9), docosadienoic acid (C22:2), docosahexaenoic acid (C22:6n3), and lingnoceric acid (C24:0), which were not detected in microorganisms but were detected in fish, were considered to have come from the commercial feed. Overall, the bacteria-supplemented diets affected changes in the amino acid (Table 3) and fatty acid (Table 4) compositions in the fish.

Table 4. Fatty acid compositions of bacterial strains and Amur catfish fed with commercial feed and $5 \%$ freeze-dried bacteria biomass-supplemented feed at end of 8-week experiment (\%) ${ }^{1,2}$.

\begin{tabular}{|c|c|c|c|c|c|c|c|c|c|c|c|}
\hline & \multicolumn{5}{|c|}{ Microorganisms (a) } & \multicolumn{6}{|c|}{ Amur Catfish (b) } \\
\hline & $\begin{array}{c}\text { B. } \\
\text { subtilis }\end{array}$ & $\begin{array}{c}\text { B. } \\
\text { albus }\end{array}$ & $\begin{array}{c}\text { B. } \\
\text { safensis }\end{array}$ & $\begin{array}{c}P . \\
\text { marinigluti- } \\
\text { nosa }\end{array}$ & P. celer & C.F ${ }^{6}$ & $\begin{array}{c}\text { B. } \\
\text { subtilis }\end{array}$ & $\begin{array}{c}\text { B. } \\
\text { albus }\end{array}$ & $\begin{array}{c}\text { B. } \\
\text { safensis }\end{array}$ & $\begin{array}{c}P . \\
\text { marinigluti- } \\
\text { nosa }\end{array}$ & P. celer \\
\hline $\mathrm{C} 12: 0$ & $2.65^{b}$ & $3.44^{\mathrm{a}}$ & $1.27^{\mathrm{d}}$ & $0.34^{\mathrm{e}}$ & $1.85^{\mathrm{c}}$ & $0.18^{a}$ & $0.13^{b}$ & $0.13^{b}$ & $0.11^{\mathrm{b}}$ & $0.10^{b}$ & $0.11^{\mathrm{b}}$ \\
\hline C14:0 & $4.26^{\mathrm{e}}$ & $5.05^{\mathrm{d}}$ & $11.14^{b}$ & $5.94^{c}$ & $13.60^{\mathrm{a}}$ & $5.04^{\mathrm{a}}$ & $4.74^{\mathrm{ab}}$ & $4.38^{b c}$ & $4.00^{\mathrm{d}}$ & $4.01^{\mathrm{d}}$ & $4.22^{\mathrm{cd}}$ \\
\hline C14:1 & & & & & & 0.06 & 0.06 & 0.07 & 0.06 & 0.05 & 0.06 \\
\hline C16:0 & $42.07^{c}$ & $48.08^{b}$ & $51.65^{\mathrm{ab}}$ & $41.33^{c}$ & $52.67^{\mathrm{a}}$ & 37.16 & 37.70 & 38.27 & 36.08 & 38.34 & 37.95 \\
\hline C16:1 & $2.24^{b}$ & $1.47^{\mathrm{c}}$ & $3.35^{\mathrm{a}}$ & $1.51^{\mathrm{c}}$ & $3.22^{\mathrm{a}}$ & $3.76^{b}$ & $4.07^{\mathrm{ab}}$ & $4.36^{\mathrm{a}}$ & $3.86^{b}$ & $3.91^{b}$ & $3.89^{b}$ \\
\hline C18:0 & $11.59^{c}$ & $13.86^{\mathrm{a}}$ & $13.73^{\mathrm{a}}$ & $12.37^{b c}$ & $12.93^{\mathrm{ab}}$ & $9.90^{b}$ & $9.96^{b}$ & $10.36^{\mathrm{b}}$ & $10.02^{b}$ & $11.22^{\mathrm{a}}$ & $10.72^{a b}$ \\
\hline C18:1n9 & $19.15^{\mathrm{a}}$ & $16.66^{b}$ & $10.84^{\mathrm{d}}$ & $15.24^{\mathrm{c}}$ & $7.87^{\mathrm{e}}$ & 18.17 & 18.40 & 18.63 & 17.68 & 18.66 & 18.95 \\
\hline C18:2n6 & $15.43^{b}$ & $9.85^{c}$ & $3.92^{d}$ & $18.70^{a}$ & $3.63^{d}$ & $13.82^{\mathrm{a}}$ & $13.79^{a b}$ & $13.55^{\mathrm{ab}}$ & $12.71^{b}$ & $13.01^{\mathrm{ab}}$ & $13.64^{\mathrm{ab}}$ \\
\hline C18:3n3 & 1.15 & 0.65 & & 1.93 & & $2.25^{a}$ & $2.14^{\mathrm{a}}$ & $1.97^{\mathrm{b}}$ & $1.85^{\mathrm{b}}$ & $1.89^{b}$ & $2.15^{\mathrm{a}}$ \\
\hline C18:3n6 & & & & & & $0.23^{c}$ & $0.25^{b c}$ & $0.29^{a}$ & $0.26^{b}$ & $0.25^{b c}$ & $0.26^{\mathrm{b}}$ \\
\hline C20:0 & & & & 0.34 & & $0.35^{b c}$ & $0.36^{b c}$ & $0.36^{b c}$ & $0.34^{c}$ & $0.44^{\mathrm{a}}$ & $0.38^{\mathrm{b}}$ \\
\hline C20:3n3 & & & & & & $0.13^{a}$ & $0.11^{a b}$ & $0.09 \mathrm{bc}$ & $0.08^{c}$ & $0.09 \mathrm{bc}$ & $0.10^{b c}$ \\
\hline C20:5n3 & & & & 0.51 & 0.95 & $1.00^{\mathrm{a}}$ & $0.87^{b}$ & 0.71 de & $0.67^{\mathrm{e}}$ & $0.76^{\mathrm{cd}}$ & $0.79^{c}$ \\
\hline C22:1n9 & & & & & & $0.13^{\mathrm{ab}}$ & $0.14^{\mathrm{ab}}$ & $0.13^{a b}$ & $0.11^{\mathrm{b}}$ & $0.15^{\mathrm{a}}$ & $0.12^{a b}$ \\
\hline C22:2 & & & & & & $0.05^{a}$ & $0.04^{\mathrm{ab}}$ & $0.03^{b}$ & $0.03^{b}$ & $0.04^{\mathrm{ab}}$ & $0.04^{\mathrm{ab}}$ \\
\hline $\mathrm{C} 22: 6 \mathrm{n} 3$ & & & & 0.23 & 0.40 & $2.98^{\mathrm{a}}$ & $2.63^{b}$ & 2.22 de & $2.12^{\mathrm{e}}$ & $2.44^{b c}$ & $2.33^{\mathrm{cd}}$ \\
\hline C24:0 & & & & & & $0.05^{\mathrm{ab}}$ & $0.05^{\mathrm{ab}}$ & $0.05^{\mathrm{ab}}$ & $0.04^{b}$ & $0.07^{\mathrm{a}}$ & $0.05^{a b}$ \\
\hline $\mathrm{SFA}^{3}$ & $61.64^{c}$ & $71.37^{b}$ & $81.79^{a}$ & $61.42^{\mathrm{c}}$ & $83.37^{a}$ & 54.07 & 54.28 & 54.82 & 51.78 & 55.55 & 54.63 \\
\hline MUFA $^{4}$ & $21.39^{a}$ & $18.13^{b}$ & $14.29^{c}$ & $17.21^{b}$ & $11.65^{\mathrm{d}}$ & 23.85 & 24.37 & 24.90 & 23.30 & 24.51 & 24.69 \\
\hline PUFA 5 & $16.97^{b}$ & $10.50^{c}$ & $3.92^{d}$ & $21.37^{\mathrm{a}}$ & $4.98^{\mathrm{d}}$ & $22.08^{b}$ & $21.35^{b c}$ & $20.28^{c}$ & $24.92^{\mathrm{a}}$ & $19.94^{\mathrm{c}}$ & $20.68^{b c}$ \\
\hline
\end{tabular}

${ }^{1}$ Values are means from triplicate groups of shrimps where the values in each row with different superscripts are significantly different $(p<0.05) .{ }^{2}$ Dry matter basis. ${ }^{3}$ Saturated fatty acid. ${ }^{4}$ Monounsaturated fatty acid. ${ }^{5}$ Polyunsaturated fatty acid. ${ }^{6}$ Commercial feed containing $47.44 \%$ protein and $5.65 \%$ lipid, Korea.

\subsection{Practical Applications and Future Research Prospects}

In summation, in the environmental field, first, general wastewater treatment at a wastewater treatment plant (WWTP) is largely divided into three stages: (i) primary treatment (removal of suspended solids); (ii) secondary treatment (removal of floating or soluble organic matter by use of microorganisms), and (iii) tertiary or advanced treatment (removal of nitrogen and phosphorus that cause eutrophication). There are various physical, chemical, and biological factors such as DO (Dissolved Oxygen), BOD (Biochemical Oxygen Demand), COD (Chemical Oxygen Demand), TOC (Total Organic Carbon), NOD 
(Nitrogenous Oxygen Demand), solids (e.g., TS, TDS, TVS, VSS, VDS, TFS, TSS), acidity, and hardness, all of which are used as water-quality measurement parameters. In the case of the biological wastewater treatment process, the removal of TN and TP is prioritized through the nitrification and denitrification processes by microorganisms. Therefore, the microorganisms used in this study can be utilized in environmental applications, because they have been shown to be excellent for water-quality-improvement purposes.

Second, in the aquaculture field, nitrite- $\mathrm{N}\left(\mathrm{NO}_{2}-\mathrm{N}\right)$ and ammonia $\left(\mathrm{NH}_{3}\right)$ are important water-quality factors, as they incur mass mortality. Nitrite- $\mathrm{N}\left(\mathrm{NO}_{2}-\mathrm{N}\right)$ occurs naturally in fresh water as a result of nitrification of ammonia and denitrification of nitrate, and its concentration is enhanced by partial oxidation of ammoniacal discharge. Its effect is manifested by the conversion of haemoglobin to methaemoglobin, which is incapable of oxygen transport; thus, nitrite is toxic to fish, including vertebrates $[55,67]$. As for total ammonia nitrogen (TAN), it represents the sum of un-ionized $\left(\mathrm{NH}_{3}\right)$ and ionized $\left(\mathrm{NH}_{4}{ }^{+}\right)$ ammonia. Acute ammonia $\left(\mathrm{NH}_{3}\right)$ toxicity, for example, affects the central nervous system of vertebrates, leading quickly to convulsions and death [68]. Ammonia $\left(\mathrm{NH}_{3}\right)^{\prime}$ 's toxicity is ascribed to its ready diffusion across gill membranes due to its lipid solubility and lack of charge, whereas ionized ammonia $\left(\mathrm{NH}_{4}{ }^{+}\right)$acts in a larger hydrated form with charged entities that cannot readily pass through the hydrophobic micropores in the gill membrane [69]. The toxicity of the forms of ammonia $\left(\mathrm{NH}_{3}\right)$ increases with water $\mathrm{pH}$ (the ammonia/ammonium ratio increases at $\mathrm{pH} 7$ and above), which is one of the reasons for the importance of $\mathrm{pH}$ control in aquaculture. Aquaculture systems including autotroph biofloc technology (ABFT) [19], biofloc technology (BFT) [70], recirculating aquaculture systems (RAS) [71], and integrated multi-trophic aquaculture (IMTA) [72] systems such as aquaponic systems [73], constructed wetlands [74], integrated marine systems [75], high-rate algal ponds [76], periphyton systems [77], and partitioned aquaculture systems [78] aim mainly to remove nitrite- $\mathrm{N}\left(\mathrm{NO}_{2}-\mathrm{N}\right)$ and ammonia $\left(\mathrm{NH}_{3}\right)$. Therefore, the four strains used in this study can be utilized in aquaculture, as they were shown to be excellent in their water-quality-improvement utilities.

Third, as a result of using the four strains as feed additives, growth was similar or higher than that of the control species (Bacillus subtilis); thus, they can be used as independent feed additives in the form of biomass (powder) in aquaculture.

Fourth and finally, the four strains of microorganisms contain essential amino acids, essential fatty acids, and bioactive substances (EPA, DHA, ARA) in their cells, and as such, can be mass-produced and used as health supplements in the food industry.

\section{Conclusions}

This study was conducted to evaluate the wastewater treatment capacity and feedadditive fish-growth effect of four strains of bacteria: Pseudoalteromonas mariniglutinosa, Psychrobacter celer, Bacillus albus, and Bacillus safensis. In the results of the wastewater degradation experiment, nitrate- $\mathrm{N}\left(\mathrm{NO}_{3}-\mathrm{N}\right)$ and nitrite- $\mathrm{N}\left(\mathrm{NO}_{2}-\mathrm{N}\right)$ were almost completely removed within $1 \mathrm{~h}$ in all of the experimental groups, and the removal rates of total ammonia nitrogen (TAN) and total nitrogen (TN) were higher in all of the experimental groups relative to the control (B. subtilis). Overall, Pseudoalteromonas mariniglutinosa was superior to the others. As for the feed additive $\left(5 \% \mathrm{Kg}^{-1}\right.$ bacteria biomass-supplemented $)$ experiment: relative to the control (commercial feed), the growth of fish was higher in all of the experimental groups (four strains), and, relative to the semi-control (B. subtilis), there was no significant difference in B. albus or B. safensis, but there was, in fact, a significant difference in Pseudoalteromonas mariniglutinosa and Psychrobacter celer. 
Author Contributions: Conceptualization, J.-Y.J. and J.-H.K.; methodology, J.-Y.J. and J.-H.K.; software, K.K.; validation, J.-H.K.; formal analysis, K.K.; investigation, J.-Y.J.; data curation, K.K.; writingoriginal draft preparation, J.-Y.J.; writing—review and editing, J.-Y.J.; visualization, K.K.; supervision, J.-Y.J. and J.-H.K.; funding acquisition, K.K. and J.-Y.J. All authors have read and agreed to the published version of the manuscript.

Funding: This research was supported by the Basic Science Research Program through the National Research Foundation of Korea (NRF) funded by the Ministry of Education (2019R1A6A3A01090640 and 2019R1A6A3A01090232).

Institutional Review Board Statement: All animal experimental procedures were performed in accordance with Gyeongsang National University Guidelines for the Care and Use of Experimental Animals approved by the Institutional Animal Care and Use Committee (IACUC) of Gyeongsang National University (GNU-191111-C0058).

Informed Consent Statement: Not applicable.

Conflicts of Interest: The authors declare no conflict of interest.

\section{References}

1. Kong, M.K.; Lee, P.C. Metabolic engineering of menaquinone-8 pathway of Escherichia coli as a microbial platform for vitamin K production. Biotechnol. Bioeng. 2011, 108, 1997-2002. [CrossRef]

2. Tarvainen, M.; Fabritius, M.; Yang, B. Determination of vitamin K composition of fermented food. Food Chem. 2019, $275,515-522$. [CrossRef]

3. Kijewski, A.; Witso, I.L.; Iversen, H.; Ronning, H.T.; L'Abee-Lund, T.; Wasteson, Y.; Lindback, T.; Aspholm, M. Vitamin K Analogs Influence the Growth and Virulence Potential of Enterohemorrhagic Escherichia coli. Appl. Environ. Microbiol. 2020, 86, e00583-20. [CrossRef]

4. Williams, D.C.; Van Frank, R.M.; Muth, W.L.; Burnett, J.P. Cytoplasmic inclusion bodies in Escherichia coli producing biosynthetic human insulin proteins. Science 1982, 215, 687-689. [CrossRef]

5. Jing, J.; Chen, Y.; Sheng, L.; Wu, M. Optimized production of insulin variant, a recombinant platelet aggregation inhibitor, by high cell-density fermentation of recombinant Escherichia coli. Protein Expr. Purif. 2018, 152, 7-12. [CrossRef]

6. Goeddel, D.V.; Kleid, D.G.; Bolivar, F.; Heyneker, H.L.; Yansura, D.G.; Crea, R.; Hirose, T.; Kraszewski, A.; Itakura, K.; Riggs, A.D. Expression in Escherichia coli of chemically synthesized genes for human insulin. Proc. Natl. Acad. Sci. USA 1979, 76, 106-110. [CrossRef]

7. DeVilbiss, S.E.; Steele, M.K.; Krometis, L.H.; Badgley, B.D. Freshwater salinization increases survival of Escherichia coli and risk of bacterial impairment. Water Res. 2021, 191, 116812. [CrossRef]

8. Blaustein, R.A.; Pachepsky, Y.; Hill, R.L.; Shelton, D.R.; Whelan, G. Escherichia coli survival in waters: Temperature dependence. Water Res. 2013, 47, 569-578. [CrossRef] [PubMed]

9. Hamilton, W.P.; Kim, M.; Thackston, E.L. Comparison of commercially available Escherichia coli enumeration tests: Implications for attaining water quality standards. Water Res. 2005, 39, 4869-4878. [CrossRef] [PubMed]

10. OHair, J.; Jin, Q.; Yu, D.; Wu, J.; Wang, H.; Zhou, S.; Huang, H. Non-sterile fermentation of food waste using thermophilic and alkaliphilic Bacillus licheniformis YNP5-TSU for 2,3-butanediol production. Waste Manag. 2021, 120, 248-256. [CrossRef] [PubMed]

11. Petrova, P.; Petlichka, S.; Petrov, K. New Bacillus spp. with potential for 2,3-butanediol production from biomass. J. Biosci. Bioeng. 2020, 130, 20-28. [CrossRef]

12. Perego, P.; Converti, A.; Del Borghi, M. Effects of temperature, inoculum size and starch hydrolyzate concentration on butanediol production by Bacillus licheniformis. Bioresour. Technol. 2003, 89, 125-131. [CrossRef]

13. Sharma, P.; Tripathi, S.; Chaturvedi, P.; Chaurasia, D.; Chandra, R. Newly isolated Bacillus sp. PS-6 assisted phytoremediation of heavy metals using Phragmites communis: Potential application in wastewater treatment. Bioresour. Technol. 2021, $320,124353$. [CrossRef]

14. Yezza, A.; Tyagi, R.D.; Valero, J.R.; Surampalli, R.Y. Bioconversion of industrial wastewater and wastewater sludge into Bacillus thuringiensis based biopesticides in pilot fermentor. Bioresour. Technol. 2006, 97, 1850-1857. [CrossRef]

15. Al-Ansari, M.M.; Benabdelkamel, H.; Al-Humaid, L. Degradation of sulfadiazine and electricity generation from wastewater using Bacillus subtilis EL06 integrated with an open circuit system. Chemosphere 2021, 276, 130-145. [CrossRef]

16. Sharp, R.J.; Scawen, M.D.; Atkinson, T. Fermentation and Downstream Processing of Bacillus. In Bacillus; Harwood, C.R., Ed.; Springer: Boston, MA, USA, 1989; pp. 255-292.

17. Cutting, S.M. Bacillus probiotics. Food Microbiol. 2011, 28, 214-220. [CrossRef] [PubMed]

18. Kim, K.; Hur, J.W.; Kim, S.; Jung, J.Y.; Han, H.S. Biological wastewater treatment: Comparison of heterotrophs (BFT) with autotrophs (ABFT) in aquaculture systems. Bioresour. Technol. 2020, 296, 122293. [CrossRef]

19. Jung, J.Y.; Damusaru, J.H.; Park, Y.; Kim, K.; Seong, M.; Je, H.W.; Kim, S.; Bai, S.C. Autotrophic biofloc technology system (ABFT) using Chlorella vulgaris and Scenedesmus obliquus positively affects performance of Nile tilapia (Oreochromis niloticus). Algal Res. 2017, 27, 259-264. [CrossRef] 
20. Cai, Z.; Li, H.; Pu, S.; Ke, J.; Wang, D.; Liu, Y.; Chen, J.; Guo, R. Development of autotrophic and heterotrophic consortia via immobilized microbial beads for chemical wastewater treatment, using PTA wastewater as an approach. Chemosphere 2021, 281, 131001. [CrossRef] [PubMed]

21. Lang, X.; Li, Q.; Xu, Y.; Ji, M.; Yan, G.; Guo, S. Aerobic denitrifiers with petroleum metabolizing ability isolated from caprolactam sewage treatment pool. Bioresour. Technol. 2019, 290, 121719. [CrossRef]

22. Xie, F.; Thiri, M.; Wang, H. Simultaneous heterotrophic nitrification and aerobic denitrification by a novel isolated Pseudomonas mendocina X49. Bioresour. Technol. 2021, 319, 124198. [CrossRef]

23. Yang, J.R.; Wang, Y.; Chen, H.; Lyu, Y.K. Ammonium removal characteristics of an acid-resistant bacterium Acinetobacter sp. JR1 from pharmaceutical wastewater capable of heterotrophic nitrification-aerobic denitrification. Bioresour. Technol. 2019, $274,56-64$. [CrossRef]

24. Arts, P.A.M.; Robertson, L.A.; Kuenen, J.G. Nitrification and denitrification by Thiosphaera pantotropha in aerobic chemostat cultures. FEMS Microbiol. Ecol. 1995, 18, 305-316. [CrossRef]

25. Chen, P.; Li, J.; Li, Q.X.; Wang, Y.; Li, S.; Ren, T.; Wang, L. Simultaneous heterotrophic nitrification and aerobic denitrification by bacterium Rhodococcus sp. CPZ24. Bioresour. Technol. 2012, 116, 266-270. [CrossRef]

26. Joo, H.S.; Hirai, M.; Shoda, M. Improvement in ammonium removal efficiency in wastewater treatment by mixed culture of Alcaligenes faecalis no. 4 and L1. J. Biosci. Bioeng. 2007, 103, 66-73. [CrossRef]

27. Nishio, T.; Yoshikura, T.; Chiba, K.; Inouye, Z. Effects of organic acids on heterotrophic nitrification by Alcaligenes faecalis OKK17. Biosci. Biotechnol. Biochem. 1994, 58, 1574-1578. [CrossRef]

28. NRC. Nutrient Requirements of Fish and Shrimp; National Academy Press: Washington, DC, USA, 2011.

29. Dawood, M.A.O.; Koshio, S.; Esteban, M.Á. Beneficial roles of feed additives as immunostimulants in aquaculture: A review. Rev. Aquac. 2018, 10, 950-974. [CrossRef]

30. Barrows, F.T. Feed additives. In Encyclopedia of Aquaculture; Stickney, R.P., Ed.; John Wiley and Sons: Hoboken, NJ, USA, 2000; pp. 335-340.

31. Geng, X.; Dong, X.H.; Tan, B.P.; Yang, Q.H.; Chi, S.Y.; Liu, H.Y.; Liu, X.Q. Effects of dietary probiotic on the growth performance, non-specific immunity and disease resistance of cobia, Rachycentron canadum. Aquac. Nutr. 2012, 18, 46-55. [CrossRef]

32. Kim, J.S.; Harikrishnan, R.; Kim, M.C.; Balasundaram, C.; Heo, M.S. Dietary administration of Zooshikella sp. enhance the innate immune response and disease resistance of Paralichthys olivaceus against Sreptococcus iniae. Fish Shellfish Immunol. 2010, 29, 104-110. [CrossRef]

33. Nayak, S.K. Role of gastrointestinal microbiota in fish. Aquac. Res. 2010, 41, 1553-1573. [CrossRef]

34. Sáenz de Rodrigáñez, M.A.; DÍaz-Rosales, P.; Chabrillón, M.; Smidt, H.; Arijo, S.; León-Rubio, J.M.; Alarcón, F.J.; Balebona, M.C.; Morinigo, M.A.; Cara, J.B.; et al. Effect of dietary administration of probiotics on growth and intestine functionality of juvenile Senegalese sole (Solea senegalensis, Kaup 1858). Aquac. Nutr. 2009, 15, 177-185. [CrossRef]

35. Duan, Y.; Zhang, Y.; Dong, H.; Wang, Y.; Zheng, X.; Zhang, J. Effect of dietary Clostridium butyricum on growth, intestine health status and resistance to ammonia stress in Pacific white shrimp Litopenaeus vannamei. Fish Shellfish Immunol. 2017, 65, 25-33. [CrossRef] [PubMed]

36. Jiang, H.F.; Liu, X.L.; Chang, Y.Q.; Liu, M.T.; Wang, G.X. Effects of dietary supplementation of probiotic Shewanella colwelliana WA64, Shewanella olleyana WA65 on the innate immunity and disease resistance of abalone, Haliotis discus hannai Ino. Fish Shellfish Immunol. 2013, 35, 86-91. [CrossRef]

37. Zhang, Z.; Schwartz, S.; Wagner, L.; Miller, W. A Greedy Algorithm for Aligning DNA Sequences. J. Comput. Biol. 2000, 7, 203-214. [CrossRef]

38. Jung, J.Y.; Hur, J.W.; Kim, K.; Han, H.S. Evaluation of floc-harvesting technologies in biofloc technology (BFT) system for aquaculture. Bioresour. Technol. 2020, 314, 123719. [CrossRef] [PubMed]

39. Paweloszek, R.; Briancon, S.; Chevalier, Y.; Gilon-Delepine, N.; Pelletier, J.; Bolzinger, M.A. Skin Absorption of Anions: Part Two. Skin Absorption of Halide Ions. Pharm. Res. 2016, 33, 1576-1586. [CrossRef]

40. AOAC. Official Methods of Analysis, 16th ed.; Association of Official Analytical Chemists: Arlington, VA, USA, 1995.

41. Folch, J.; Lees, M.; Stanley, G.H.S. A Simple Method for the Isolation and Purification of Total Lipides from Animal Tissues. J. Biol. Chem. 1957, 226, 497-509. [CrossRef]

42. Li, W.; Ai, Q.; Mai, K.; Xu, W.; Luo, Y.; Zhang, Y. Effects of dietary amino acid patterns on growth and protein metabolism of large yellow croaker (Larimichthys crocea) larvae. Aquaculture 2013, 406-407, 1-8. [CrossRef]

43. Wirasnita, R.; Hadibarata, T.; Novelina, Y.M.; Yusoff, A.R.M.; Yusop, Z. A Modified Methylation Method to Determine Fatty Acid Content by Gas Chromatography. Bull. Korean Chem. Soc. 2013, 34, 3239-3242. [CrossRef]

44. Zaghloul, T.I.; Embaby, A.M.; Elmahdy, A.R. Biodegradation of chicken feathers waste directed by Bacillus subtilis recombinant cells: Scaling up in a laboratory scale fermentor. Bioresour. Technol. 2011, 102, 2387-2393. [CrossRef]

45. Lu, L.; Tan, H.; Luo, G.; Liang, W. The effects of Bacillus subtilis on nitrogen recycling from aquaculture solid waste using heterotrophic nitrogen assimilation in sequencing batch reactors. Bioresour. Technol. 2012, 124, 180-185. [CrossRef]

46. Wattiau, P.; Renard, M.E.; Ledent, P.; Debois, V.; Blackman, G.; Agathos, S.N. A PCR test to identify Bacillus subtilis and closely related species and its application to the monitoring of wastewater biotreatment. Appl. Microbiol. Biotechnol. 2001, 56, 816-819. [CrossRef] [PubMed] 
47. Hureiki, L.; Croué, J.P.; Legube, B. Chlorination studies of free and combined amino acids. Water Res. 1994, $28,2521-2531$. [CrossRef]

48. Pehlivanoglu-Mantas, E.; Sedlak, D.L. Wastewater-Derived Dissolved Organic Nitrogen: Analytical Methods, Characterization, and Effects-A Review. Crit. Rev. Environ. Sci. Technol. 2006, 36, 261-285. [CrossRef]

49. Huo, S.; Xi, B.; Yu, H.; Qin, Y.; Zan, F.; Zhang, J. Characteristics and transformations of dissolved organic nitrogen in municipal biological nitrogen removal wastewater treatment plants. Environ. Res. Lett. 2013, 8, 044005. [CrossRef]

50. Chen, J.; Xu, J.; Zhang, S.; Liu, F.; Peng, J.; Peng, Y.; Wu, J. Nitrogen removal characteristics of a novel heterotrophic nitrification and aerobic denitrification bacteria, Alcaligenes faecalis strain WT14. J. Environ. Manage. 2021, 282, 111961. [CrossRef]

51. Rout, P.R.; Bhunia, P.; Dash, R.R. Simultaneous removal of nitrogen and phosphorous from domestic wastewater using Bacillus cereus GS-5 strain exhibiting heterotrophic nitrification, aerobic denitrification and denitrifying phosphorous removal. Bioresour. Technol. 2017, 244, 484-495. [CrossRef]

52. Xu, N.; Liao, M.; Liang, Y.; Guo, J.; Zhang, Y.; Xie, X.; Fan, Q.; Zhu, Y. Biological nitrogen removal capability and pathways analysis of a novel low $\mathrm{C} / \mathrm{N}$ ratio heterotrophic nitrifying and aerobic denitrifying bacterium (Bacillus thuringiensis strain WXN-23). Environ. Res. 2021, 195, 110797. [CrossRef]

53. Ebeling, J.M.; Timmons, M.B.; Bisogni, J.J. Engineering analysis of the stoichiometry of photoautotrophic, autotrophic, and heterotrophic removal of ammonia-nitrogen in aquaculture systems. Aquaculture 2006, 257, 346-358. [CrossRef]

54. Ye, J.; Zhao, B.; An, Q.; Huang, Y.S. Nitrogen removal by Providencia rettgeri strain YL with heterotrophic nitrification and aerobic denitrification. Environ. Technol. 2016, 37, 2206-2213. [CrossRef] [PubMed]

55. Kim, K.; Jung, J.Y.; Han, H.S. Utilization of Microalgae in Aquaculture System: Biological Wastewater Treatment. Emerg. Sci. J. 2019, 3, 209-221. [CrossRef]

56. Lu, L.; Wang, G.; Yeung, M.; Xi, J.; Hu, H.-Y. Shift of microbial community in gas-phase biofilters with different inocula, inlet loads and nitrogen sources. Process Biochem. 2020, 91, 57-64. [CrossRef]

57. Schilling, O.; Frick, O.; Herzberg, C.; Ehrenreich, A.; Heinzle, E.; Wittmann, C.; Stulke, J. Transcriptional and metabolic responses of Bacillus subtilis to the availability of organic acids: Transcription regulation is important but not sufficient to account for metabolic adaptation. Appl. Environ. Microbiol. 2007, 73, 499-507. [CrossRef]

58. Lins Rodigues, M.; Damasceno, D.Z.; Gomes, R.L.M.; Sosa, B.d.S.; Moro, E.B.; Boscolo, W.R.; Bittencourt, F.; Signor, A. Probiotic effects (Bacillus cereus and Bacillus subtilis) on growth and physiological parameters of silver catfish (Rhamdia quelen). Aquac. Nutr. 2020, 27, 454-467. [CrossRef]

59. Wang, Y.; Wang, Q.; Xing, K.; Jiang, P.; Wang, J. Dietary cinnamaldehyde and Bacillus subtilis improve growth performance, digestive enzyme activity, and antioxidant capability and shape intestinal microbiota in tongue sole, Cynoglossus semilaevis. Aquaculture 2021, 531, 735798. [CrossRef]

60. Zhou, S.; Song, D.; Zhou, X.; Mao, X.; Zhou, X.; Wang, S.; Wei, J.; Huang, Y.; Wang, W.; Xiao, S.M.; et al. Characterization of Bacillus subtilis from gastrointestinal tract of hybrid Hulong grouper (Epinephelus fuscoguttatus $\times$ E. lanceolatus) and its effects as probiotic additives. Fish Shellfish Immunol. 2019, 84, 1115-1124. [CrossRef] [PubMed]

61. Kim, K.; Park, Y.; Je, H.W.; Seong, M.; Damusaru, J.H.; Kim, S.; Jung, J.Y.; Bai, S.C. Tuna byproducts as a fish-meal in tilapia aquaculture. Ecotoxicol. Environ. Saf. 2019, 172, 364-372. [CrossRef] [PubMed]

62. Robinson, E.H.; Jackson, L.S.; Li, M.H.; Kingsbury, S.K.; Tucker, C.S. Effect of Time of Feeding on Growth of Channel Catfish. J. World Aquacult. Soc. 1995, 26, 320-322. [CrossRef]

63. Hallier, A.; Serot, T.; Prost, C. Influence of rearing conditions and feed on the biochemical composition of fillets of the European catfish (Silurus glanis). Food Chem. 2007, 103, 808-815. [CrossRef]

64. Jiang, J.; Xu, S.; Feng, L.; Liu, Y.; Jiang, W.; Wu, P.; Wang, Y.; Zhao, Y.; Zhou, X. Lysine and methionine supplementation ameliorates high inclusion of soybean meal inducing intestinal oxidative injury and digestive and antioxidant capacity decrease of yellow catfish. Fish Physiol. Biochem. 2018, 44, 319-328. [CrossRef]

65. Mondal, K.; Kaviraj, A.; Mukhopadhyay, P.K. Evaluation of fermented fish-offal in the formulated diet of the freshwater catfish Heteropneustes fossilis. Aquac. Res. 2008, 39, 1443-1449. [CrossRef]

66. Wang, F.; Ma, X.; Wang, W.; Liu, J. Comparison of proximate composition, amino acid and fatty acid profiles in wild, pond- and cage-cultured longsnout catfish (Leiocassis longirostris). Int. J. Food Sci. Technol. 2012, 47, 1772-1776. [CrossRef]

67. Eddy, F.B.; Williams, E.M. Nitrite and Freshwater Fish. Chem. Ecol. 1987, 3, 1-38. [CrossRef]

68. Ip, Y.K.; Chew, S.F.; Leong, I.A.; Jin, Y.; Lim, C.B.; Wu, R.S. The sleeper Bostrichthys sinensis (family Eleotridae) stores glutamine and reduces ammonia production during aerial exposure. J. Comp. Physiol. B 2001, 171, 357-367. [CrossRef] [PubMed]

69. Svobodova, Z.; Lloyd, R.; Machova, J. Water Quality and Fish Health; Food and Agriculture Organization of the United Nations: Roma, Italy, 1993.

70. Kim, Y.-S.; Kim, S.-E.; Kim, S.-J.; Jung, H.-K.; Park, J.; Jeon, Y.J.; Kim, D.-H.; Kang, J.-H.; Kim, K.-H. Effects of wheat flour and culture period on bacterial community composition in digestive tracts of Litopenaeus vannamei and rearing water in biofloc aquaculture system. Aquaculture 2021, 531, 735908. [CrossRef]

71. Liu, W.; Du, X.; Tan, H.; Xie, J.; Luo, G.; Sun, D. Performance of a recirculating aquaculture system using biofloc biofilters with convertible water-treatment efficiencies. Sci. Total Environ. 2021, 754, 141918. [CrossRef]

72. Chang, Y.C.; Ma, C.H.; Lee, H.T.; Hsu, T.H. Polyculture of Juvenile Dog Conch Laevistrombus canarium Reveals High Potentiality in Integrated Multitrophic Aquaculture (IMTA). Biology 2021, 10, 812. [CrossRef] 
73. Lobanov, V.P.; Combot, D.; Pelissier, P.; Labbe, L.; Joyce, A. Improving Plant Health Through Nutrient Remineralization in Aquaponic Systems. Front Plant Sci. 2021, 12, 683690. [CrossRef] [PubMed]

74. Gorito, A.M.; Lado Ribeiro, A.R.; Pereira, M.F.R.; Almeida, C.M.R.; Silva, A.M.T. Advanced oxidation technologies and constructed wetlands in aquaculture farms: What do we know so far about micropollutant removal? Environ. Res. 2021, 204, 111955. [CrossRef] [PubMed]

75. Giraud, E.; Douet, D.G.; Le Bris, H.; Bouju-Albert, A.; Donnay-Moreno, C.; Thorin, C.; Pouliquen, H. Survey of antibiotic resistance in an integrated marine aquaculture system under oxolinic acid treatment. FEMS Microbiol. Ecol. 2006, 55, 439-448. [CrossRef]

76. Pagand, P.; Blancheton, J.-P.; Lemoalle, J.; Casellas, C. The use of high rate algal ponds for the treatment of marine effluent from a recirculating fish rearing system. Aquac. Res. 2000, 31, 729-736. [CrossRef]

77. Azim, M.E.; Wahab, M.A.; Dam, A.A.v.; Beveridge, M.C.M.; Huisman, E.A.; Verdegem, M.C.J. Optimization of stocking ratios of two Indian major carps, rohu (Labeo rohita Ham.) and catla (Catla catla Ham.) in a periphyton-based aquaculture system. Aquaculture 2001, 203, 33-49. [CrossRef]

78. Brune, D.E.; Schwartz, G.; Eversole, A.G.; Collier, J.A.; Schwedler, T.E. Partitioned Aquaculture Systems. In Biology and Culture of Channel Catfish; Tucker, C.S., Hargreaves, J.A., Eds.; Elsevier Science: Amsterdam, The Netherlands, 2004; pp. 561-584. 